\title{
Triploid or hybrid tetra: Which is the ideal sterile host for surrogate technology?
}

\author{
Lucas Henrique Piva $^{\text {a, b }}$, Diógenes Henrique de Siqueira-Silva b, c, d, *, \\ Caio Augusto Gomes Goes ${ }^{\mathrm{e}}$, Takafumi Fujimoto ${ }^{\mathrm{f}}$, Taiju Saito ${ }^{\mathrm{g}}$, Letícia Veroni Dragone ${ }^{\mathrm{b}}$, \\ José Augusto Senhorini ${ }^{\mathrm{b}}$, Fabio Porto-Foresti ${ }^{\mathrm{e}}$, José Bento Sterman Ferraz ${ }^{\mathrm{d}}$, \\ George Shigueki Yasui ${ }^{\text {b, }}{ }^{\text {, *** }}$
}

\footnotetext{
${ }^{a}$ UNESP - Univ. Estadual Paulista, Campus de Botucatu, Programa de Pós-Graduação Em Ciências Biológicas (Zoologia), Botucatu, São Paulo, Brazil

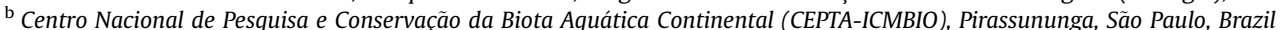

' UNIFESSPA - Universidade Federal Do Sul e Sudeste Do Pará. Instituto de Estudo Em Saúde e Biológicas (IESB), Marabá, Pará, Brazil

d USP-University of São Paulo, Faculdade de Zootecnia e Engenharia de Alimentos, Departamento de Medicina Veterinária, Pirassununga, São Paulo, Brazil

e UNESP - Univ. Estadual Paulista, Campus de Bauru, Faculdade de Ciências, Bauru, São Paulo, Brazil

${ }^{\mathrm{f}}$ Faculty of Fisheries Sciences, Hokkaido University, 3-1-1 Minato-cho, 041-8611 Hakodate, Japan

${ }^{g}$ Nishiura Station, South Ehime Fisheries Research Center, Ehime University, Uchidomari, Ainan, Japan
}

\section{A R T I C L E I N F O}

\section{Article history:}

Received 16 May 2017

Received in revised form

2 December 2017

Accepted 3 December 2017

Available online 7 December 2017

\section{Keywords:}

Fish chimera

Germ cell transplantation

Sterile fish

Tetra

\begin{abstract}
A B S T R A C T
This work was aimed at developing an effective procedure to obtain sterile ideal host fish in mass scale with no endogenous germ cells in the germinal epithelium, owning permanent stem-cell niches able to be colonized by transplanted germ cells in surrogate technology experiments. Thus, triploids, diploid hybrids, and triploid hybrids were produced. To obtain hybrid offspring, oocytes from a single Astyanax altiparanae female were inseminated by sperm from five males (A. altiparanae, A. fasciatus, A. schubarti, Hyphessobrycon anisitsi, and Oligosarcus pintoi). Triploidization was conducted by inhibition of the second polar body release using heat shock treatment at $40{ }^{\circ} \mathrm{C}$ for $2 \mathrm{~min}$. At 9-months of age, the offspring from each crossing was histologically evaluated to access the gonadal status of the fish. Variable morphological characteristics of the gonads were found in the different hybrids offspring: normal gametogenesis, gametogenesis without production of gametes, sterile specimens holding germ cells, and sterile specimens without germ cells, which were considered "ideal hosts". However, only in the hybrid derived from crossing between $A$. altiparanae and A. fasciatus, $100 \%$ of the individuals were completely sterile. Among them $83.3 \%$ of the male did not present germ cells inside germinal epithelium, having only somatic cells in the gonad. The other $16.7 \%$ also presented spermatogonia inside the niches. Such a methodology allows the production of sterile host in mass scale, opening new insights for application of surrogate technologies.
\end{abstract}

(c) 2017 Elsevier Inc. All rights reserved.

\footnotetext{
* Corresponding author. Diógenes Henrique de Siqueira-Silva - UNIFESSPA Universidade Federal do Sul e Sudeste do Pará, Instituto de Estudo em Saúde e Biológicas (IESB), Marabá, Pará, Brazil. Folha 31, Quadra 07, Lote especial s/n Nova Marabá, Marabá, PA CEP: 68.507-590, Brazil.

** Corresponding author. Diógenes Henrique de Siqueira-Silva - UNIFESSPA Universidade Federal do Sul e Sudeste do Pará, Instituto de Estudo em Saúde e Biológicas (IESB), Marabá, Pará, Brazil. Folha 31, Quadra 07, Lote especial s/n Nova Marabá, Marabá, PA CEP: 68.507-590, Brazil.

E-mail addresses: diogenessilva@unifesspa.edu.br (D.H. de Siqueira-Silva), siqueira.diogenes@gmail.com (G.S. Yasui).
}

\section{Introduction}

Germ cell transplantation in fish is an interesting reproductive technology that allows for one fish species to produce gametes from another [1]. Such a technique, also known as surrogate technology, involves the production of heterologous gametes being applicable in aquaculture and conservation since rare strains or species may be produced from farmed or laboratory fish in which reproductive aspects are well established. Genebanking using surrogate technologies is effective since genetic variability and maternal components, such as mitochondrial DNA and germ plasm, are maintained [2]. 
In order to perform such a surrogate production, it is first necessary to produce a germline chimera in which the germ cell lineage from a donor species is transplanted to a target sterile host species, whose endogenous gametogenesis is suppressed, to ensure a restrictive maturation, exclusively of the transplanted germ cells.

Hybrid and triploid fish are well known to be sterile for several species [3]. Yamaha et al. [4], for example, used hybrid fish and transplanted PGCs that successfully colonized genital ridges and followed spermatogenesis. Similarly, Okutsu et al. [5] transplanted spermatogonial stem cells from rainbow trout into sterile triploid masu salmon 0 . masou, and only gametes from donor species were obtained after sexual maturation. However, the gonads of some triploid species and hybrids are occupied by endogenous germ cells $[6,7]$. In such cases, it theoretically may be a limitation for the colonization of the transplanted cells, since an ideal host must present a sterile gonad without germ cells because the niches are necessary for colonization, proliferation, and maturation of the transplanted germ cells. This may increase the colonization success and ensure the production of heterologous gametes.

Thus, the aim of the present study was to establish an appropriate host, which can be produced in large scale for surrogate technologies in threatened fish for example, such as the piracanjuba Brycon orbgnyanus. This particular fish is currently listed as critically endangered and at high risk of extinction in the wild in the near future, according to the Red Book of Brazilian Fauna Threatened with Extinction [8]. Given this, five tetra species (Astyanax altiparanae, A. fasciatus, A schubarti, Oligosarcus pintoi, and Hyphessobrycon anisitsi) were chosen for their good livestock characteristics, such as ease of handling, small size, early sexual maturity, and intertidal spawning, which make them appropriate models for the development of such a methodological approach.

\section{Material and methods}

\subsection{Origin of broodstock and gamete sampling}

All the procedures were performed in line with the Ethical Committee for the Use of Laboratory for the Care and Use of Laboratory Animals in Chico Mendes Institute (CEUA - CEPTA \#02031.000033/2015-11).

The yellowtail tetra (Astyanax altiparanae) used in this study were collected from the Mogi Guaçu river (21.925706 S, $47.369496 \mathrm{~W})$ and maintained in $1000 \mathrm{~m}^{2}$ earthen ponds $(\approx 500$ fish per tank, $\mathrm{SL} \approx 12 \mathrm{~cm}$ ). As this species spawn spontaneously, F1 offspring were produced within few months and then were used fish in this work. Adult males from A. schubarti $(\approx 6 \mathrm{~cm})$, A. fasciatus ( $\approx 8 \mathrm{~cm}$ ), and Oligosarcus pintoi $(\approx 5 \mathrm{~cm}$ ) were collected in the Mogi Guaçu River and maintained in 600-L aquariums for sperm sampling. Albino males of Hyphessobrycon anisitsi $(\approx 5 \mathrm{~cm})$ were obtained from a commercial fish dealer. Males were identified by the bony hooks on the anal fin, which can be also identified by gently hand-touching. Some of Oligosarcus pintoi males did not present bony hooks and were identified only by external morphology, in which the males are smaller and thinner than females.

Ovulation in A. altiparanae was induced using the previous protocol of this lab [9]. Briefly, ovulation of females from A. altiparanae $(\mathrm{SL} \approx 9 \mathrm{~cm})$ and spermiation of males from other species were induced by a single dose of carp pituitary gland $\left(5 \mathrm{mg} \mathrm{kg}^{-1}\right)$. After $10 \mathrm{~h}$ at $28{ }^{\circ} \mathrm{C}$, the fish were anesthetized using menthol (Exodo, Científica) at $100 \mathrm{mg} \mathrm{L}^{-1}$, and the gametes were collected by stripping. The sperm was collected using a $1000 \mu \mathrm{l}$ micropipette (Eppendorf, Hamburg, Germany). The sampled sperm was transferred to a $1.5 \mathrm{~mL}$ tube containing $300 \mu \mathrm{l}$ of modified Ringer solution (128.3 mM NaCl, $23.6 \mathrm{mM} \mathrm{KCl}, 3.6 \mathrm{mM} \mathrm{CaCl}_{2}, 2.1 \mathrm{mM} \mathrm{MgCl}_{2}$ ), mixed by gently pipetting, and stored at $2.5{ }^{\circ} \mathrm{C}$. The sperm quality was immediately assessed on the microscope after striping using another previous protocol [9], and sperm samples with progressive motility above $80 \%$ were used for fertilization trials.

Oocytes were stripped on a plastic Petri dish (90 mm diameter) covered by a polyvinylidene chloride film (saran wrap, Alpfilm, São Paulo, Brazil). Oocytes were covered by a small piece of the same polyvinylidene chloride film to avoid dehydration until the fertilization trials, which was performed right after oocyte extrusion.

\subsection{Triploidization and juvenile rearing}

Oocytes from a single female ( $\approx 8000$ oocytes) were divided into 5 Petri dishes and inseminated using $80 \mu$ of sperm from 5 males (A. altiparanae, A. fasciatus, A. schubarti, H. anisitsi, O. pintoi), respectively. Gamete activation was achieved by adding $5 \mathrm{~mL}$ of water and, then, immediately mixed by gentle hand mixing. Each egg batch was divided into two plastic containers in which the bottom contained a $100 \mu \mathrm{m}$ nylon mesh and maintained at $22{ }^{\circ} \mathrm{C}$. One egg batch from each was induced to triploidization, and the remaining egg batch were kept intact. Triploidization was performed using a previous protocol of this lab [10], using the timing obtained by cytological observation that showed that extrusion of 2nd polar body occurs at $8 \mathrm{mpf}$ [11]. At $2 \mathrm{~min}$ post fertilization (mpf), the eggs were heat shocked at $40{ }^{\circ} \mathrm{C}$ for $2 \mathrm{~min}$. After heat shocking, the eggs were immediately transferred to incubation at $25^{\circ} \mathrm{C}$. Hatching took place at $12 \mathrm{~h}$ post-fertilization (Fig. 1).

Juveniles were maintained in $40 \mathrm{~L}$ aquariums in a recirculation system. The temperature was set at $28^{\circ} \mathrm{C}$ and $12 \mathrm{~h}$ of light. After 3 days post fertilization, the juveniles were fed three times a day using new-hatched Artemia salina nauplii for 10 days, and after this period, the fish were fed with powdered commercial food (4200 kcaL kg-1 and 45\% crude protein). As the fish grew up, the feeding was changed to $1 \mathrm{~mm}$-pellets and natural plankton until the end of the experiment.

\subsection{Ploidy confirmation}

The ploidy status from the adult fish was measured from each cross by flow cytometry using the developed protocol for preservation and analysis from this lab [12]. Briefly, small pieces of fin $\left(\approx 2 \mathrm{~mm}^{2}\right)$ were clipped and frozen in $0.9 \% \mathrm{NaCl}$ for future analysis. Later, the samples were thawed, and the $\mathrm{NaCl}$ solution was replaced by a lysing solution $\left(9.53 \mathrm{mM} \mathrm{MgCl} 2.7 \mathrm{H}_{2} 0 ; 47.67 \mathrm{mM} \mathrm{KCl} ; 15 \mathrm{mM}\right.$ Tris; $74 \mathrm{mM}$ sucrose, $0.6 \%$ Triton X-100, $\mathrm{pH} 8.0$ ) and vortexed. After $30 \mathrm{~min}, 1.5 \mathrm{~mL}$ of staining solution (calcium-free Dulbecco's PBS with 4',6-diamidino-2-phenylindole - DAPI at $1 \mu \mathrm{g} \mathrm{mL} \mathrm{m}^{-1}$ ) was added and immediately filtered by a $30 \mu \mathrm{m}$ mesh (Celltrics, Partec, Münster, Germany). Stained samples were then analyzed by a Partec CyFlow Plody Analyzer (Partec GmbH, Münster, Germany) with a specific filter set for DAPI excitation $(358 \mathrm{~nm})$. The relative DNA content was determined based on the histograms in which diploid $A$. altiparanae were used as controls.

\subsection{Histological analysis}

For histological analysis, the specimens were anesthetized using 2-Phenoxy-Ethanol $\left(\mathrm{C}_{6} \mathrm{H}_{10} \mathrm{O}_{2}-\right.$ SIGMA-ALDRICH), their gonads were removed, cut into transverse and longitudinal sections, and fixed with Bouin's fixative (Picric Acid P.A., Ethyl alcohol 96\% or 99\%, Formaldehyde P.A., Glacial Acid Acetic - Cinetica; Adria laboratories, Brazil) for $24 \mathrm{~h}$. Samples were dehydrated in grade ethanol solution, embedded in paraffin - polyisobutylene mixture (Paraplast $^{\circledR}$, SIGMA-ALDRICH), sectioned at $3.0 \mu \mathrm{m}$ on a microtome (Leica RM2235, Germany) equipped with steel blade (Leica 818), and sections were then stained with hematoxylin and eosin. All 


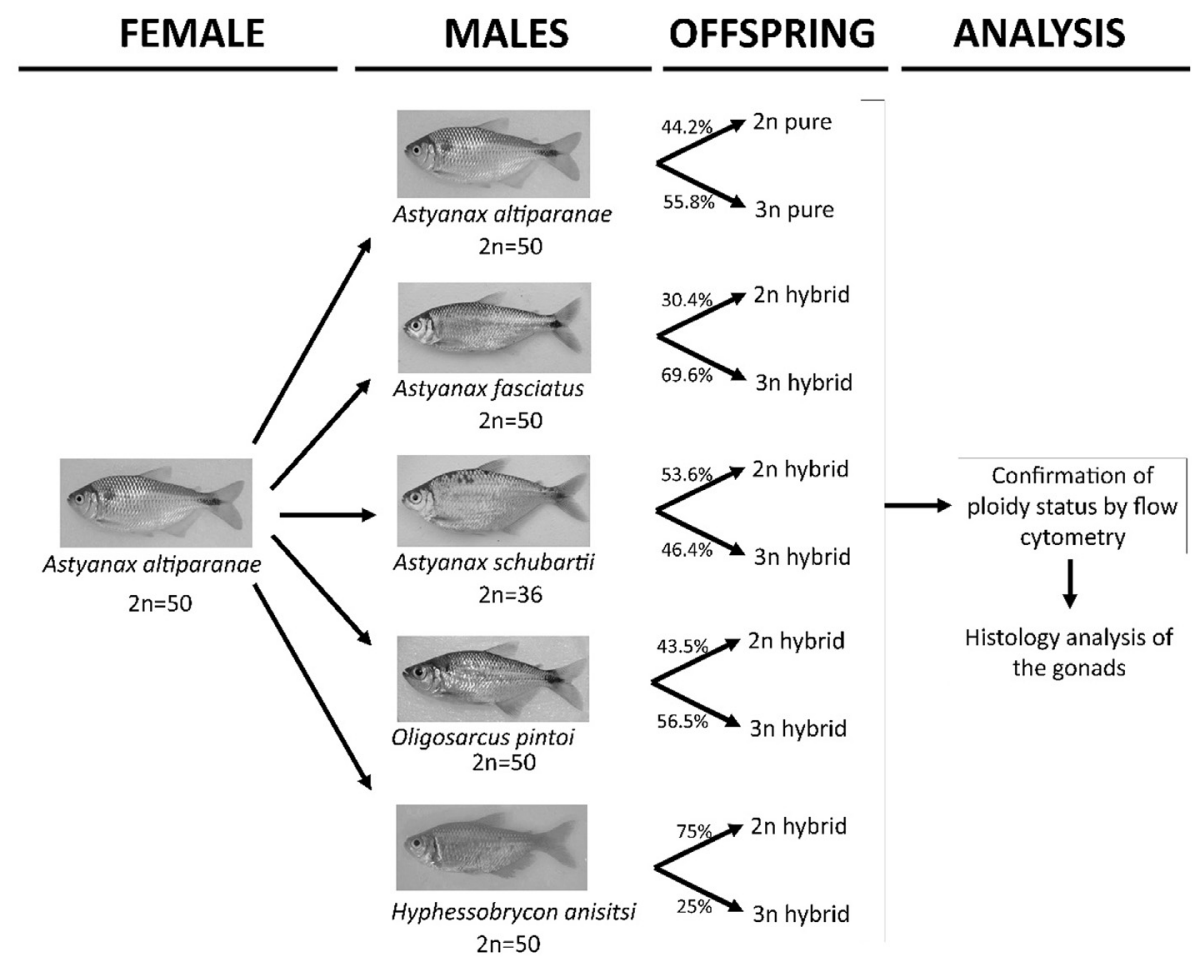

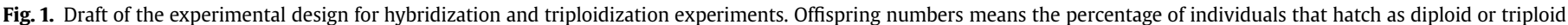
after the crosses.

material was microscopically examined on a microscope (NikonEclipse CI, Japan), digital images were captured with a CCD camera (Nikon DSF1, Nikon, Tokyo, Japan), and analyzed with NIS-Elements AR software (Nikon, Tokyo, Japan). Four morphological types of gonads were observed among the offspring: 1) Normal gametogenesis (specimens showing normal gametogenesis; 2 ) No gametes (specimens showing normal gametogenesis without production of gametes; 3) Sterile with germ cells (specimens showing mainly oogonia, in case of female, and spermatogonia, in case of male, into their gonads); and 4) Sterile without germ cells (specimens showing only somatic cells into their gonads).

\section{Results}

Table 1 summarizes embryo development and survival rates of offspring resulting from the different crosses of specimens originating from hybridization and triploidization processes. The number of hatching larvae presenting normal shape was very similar among most of the treatments, except the crosses involving triploid of $H$. anisitsi that had a higher number of individuals (282) and 0 . pintoi diploid and triploid that showed the lowest number of surviving specimens 77 and 67, respectively.

In Table 2, it is possible to observe that $A$. altiparanae crosses did not cause deviation in the $1: 1$ sex ratio for both diploid $\left(\mathrm{x}^{2}=1.316\right)$ and triploid $\left(x^{2}=2.666\right)$ fish. However, in other crosses involving A. fasciatus diploids $\left(\mathrm{x}^{2}=7\right)$ and triploids $\left(\mathrm{x}^{2}=4\right)$, A. schubarti triploid $\left(x^{2}=6.231\right)$, and 0 . pintoi triploids $\left(x^{2}=9.308\right)$ resulted in an increased number of male.

In Fig. 2, is possible to observe the main morphological characteristics of the gonads in the resultant offspring.

Table 1

Embryo development and survival rate of the offspring from each cross between Astyanax altiparanae female and the male of the other studied species.

\begin{tabular}{|c|c|c|c|c|c|c|c|c|c|}
\hline Species & & $\begin{array}{l}\text { Proportion } 2 n / \\
3 n\end{array}$ & $\begin{array}{l}\text { Number of eggs } \\
\text { used }\end{array}$ & $\begin{array}{l}\text { Blastula stages } \\
(\%)\end{array}$ & $\begin{array}{l}\text { Gastrula stages } \\
(\%)\end{array}$ & $\begin{array}{l}\text { Segmentation stages } \\
(\%)\end{array}$ & Hatching (\%) & $\begin{array}{l}\text { Normal larvae } \\
(\%)\end{array}$ & $\begin{array}{l}\text { Normal } \\
\text { larvae }\end{array}$ \\
\hline \multirow[t]{2}{*}{ Astyanax altiparanae } & Control & $57 / 3$ & 359 & $86,39 \pm 4,07$ & $79,91 \pm 6,10$ & $76,44 \pm 7,40$ & $64,17 \pm 9,58$ & $77,42 \pm 9,39$ & 176 \\
\hline & $\begin{array}{l}\text { Heat } \\
\text { shock }\end{array}$ & $8 / 52$ & 413 & $81,98 \pm 1,98$ & $81,39 \pm 1,72$ & $77,97 \pm 2,87$ & $75,54 \pm 2,90$ & $76,27 \pm 10,15$ & 223 \\
\hline \multirow[t]{2}{*}{ Astyanax fasciatus } & Control & $55 / 2$ & 304 & $86,05 \pm 6,07$ & $84,74 \pm 5,87$ & $83,07 \pm 5,51$ & $75,57 \pm 9,00$ & $90,91 \pm 4,26$ & 209 \\
\hline & $\begin{array}{l}\text { Heat } \\
\text { shock }\end{array}$ & $1 / 39$ & 360 & $92,24 \pm 0,78$ & $89,30 \pm 1,50$ & $84,55 \pm 2,87$ & $67,40 \pm 5,18$ & $66,01 \pm 16,35$ & 149 \\
\hline \multirow[t]{2}{*}{ Astyanax schubarti } & Control & $35 / 3$ & 292 & $81,59 \pm 3,98$ & $80,04 \pm 2,43$ & $79,01 \pm 1,40$ & $76,43 \pm 1,18$ & $92,04 \pm 0,26$ & 115 \\
\hline & $\begin{array}{l}\text { Heat } \\
\text { shock }\end{array}$ & $9 / 31$ & 452 & $75,55 \pm 9,35$ & $70,62 \pm 7,24$ & $68,54 \pm 7,97$ & $61,76 \pm 4,01$ & $86,14 \pm 6,55$ & 194 \\
\hline \multirow[t]{2}{*}{ Oligosarcus pintoi } & Control & $28 / 0$ & 283 & $79,63 \pm 9,73$ & $67,90 \pm 2,31$ & $64,71 \pm 0,88$ & $61,52 \pm 4,07$ & $81,69 \pm 15,03$ & 77 \\
\hline & $\begin{array}{l}\text { Heat } \\
\text { shock }\end{array}$ & $4 / 31$ & 220 & $77,99 \pm 15,34$ & $74,29 \pm 14,05$ & $70,44 \pm 16,22$ & $59,61 \pm 5,39$ & $79,74 \pm 0,26$ & 67 \\
\hline \multirow{2}{*}{$\begin{array}{l}\text { Hyphessobrycon } \\
\text { anisitsi }\end{array}$} & Control & $60 / 0$ & 339 & $78,40 \pm 10,40$ & $76,74 \pm 9,66$ & $76,16 \pm 9,47$ & $71,95 \pm 8,19$ & $85,31 \pm 10,71$ & 202 \\
\hline & $\begin{array}{l}\text { Heat } \\
\text { shock }\end{array}$ & $13 / 42$ & 520 & $76,87 \pm 10,08$ & $74,70 \pm 10,00$ & $71,09 \pm 11,52$ & $66,13 \pm 11,93$ & $81,90 \pm 8,12$ & 282 \\
\hline
\end{tabular}


Table 2

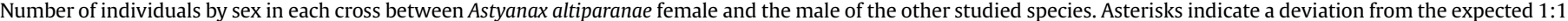
sex ratio by the chi-square test $\left(\chi^{2}<0.05\right)$.

\begin{tabular}{|c|c|c|c|c|c|c|c|c|c|c|}
\hline & \multicolumn{2}{|c|}{ Astyanax altiparanae } & \multicolumn{2}{|c|}{ Astyanax fasciatus } & \multicolumn{2}{|c|}{ Astyanax schubarti } & \multicolumn{2}{|c|}{ Oligosarcus pintoi } & \multicolumn{2}{|c|}{$\begin{array}{l}\text { Hyphessobrycon } \\
\text { anisitsi }\end{array}$} \\
\hline & Male & Female & Male & Female & Male & Female & Male & Female & Male & Female \\
\hline Diploid & 7 & 12 & 7 & $0^{*}$ & 11 & 4 & 6 & 4 & 8 & 13 \\
\hline Triploid & 8 & 16 & 12 & $4^{*}$ & 11 & $2^{*}$ & 12 & $1^{*}$ & 6 & 1 \\
\hline
\end{tabular}

\subsection{A. altiparanae $\times$ A. altiparanae crossing}

As expected, diploid $A$. altiparanae progeny were not sterile. Males presented the entire germ cell lineage including spermatogonia, spermatocytes, spermatids, and fully-grown spermatozoa (S1, Table 3). Similarly, females presented previtellogenic and vitellogenic oocytes (Normal gametogenesis) (S1, Table 3). However, triploid A. altiparanae progeny presented some gametogenesis abnormality. All the male specimens presented apparently normal spermatogenesis, but no spermatozoa were visible in the lumen (No gametes). Furthermore, seminal fluid, which normally appear in diploid fish testes dyed by eosin (S1), was not found in the lumen in these triploid fish testes (S1, Table 3). Regarding the females, 14 out of 16 were sterile, presenting ovaries full of oogonia with rare previtellogenic, but there were no vitellogenic oocytes (S1, Table 3). The other two females, similar to diploid specimens, presented normal oogenesis (Table 3).

\subsection{A. altiparanae $\times$ A. fasciatus crossing}

Diploid progeny of A. altiparanae x A. fasciatus crossing were all male. One out of the seven individuals showed normal spermatogenesis ( $\mathrm{S} 2$, Table 3), five of them were sterile presenting the epithelium filled only by spermatogonia (S2, Table 3), and one specimen showed no germ cells into the seminiferous compartment, which was composed only by somatic cells (S2, Table 3 ). In relation to triploid progeny, all of them were sterile, being that two out of 12 males presented only spermatogonia inside the germinal epithelium, similar to the diploid sterile, and the other 10 individuals held no germ cells (S2, Table 3 ). Female ovaries were very thin, showing only oogonia in the epithelium (S2, Table 3).

\subsection{A. altiparanae $\times$ A. schubarti crossing}

In diploid hybrids resulting from the A. altiparanae and A. schubarti crossing, one out of four females was sterile, having ovaries full of oogonia and rare previtellogenic and vitellogenic oocytes (S3, Table 3). The other three specimens showed normal oogenesis (S3, Table 3). Among the males, six specimens were sterile, presenting filiform testes filled only by spermatogonia (S3, Table 3), and five of them, such as the triploid A. altiparanae, presented apparently normal gametogenesis, but there were no fully grown spermatozoa inside the lumen. However, different from that of triploid A. altiparanae, these individuals had seminal fluid inside the luminal compartment (S3, Table 3). Among triploid female, only two individuals arise, one showing normal oogenesis and another one was sterile. Their ovaries presented characteristics that were very similar to that of diploid females. Among triploid males, six out of 11 specimens presented normal spermatogenesis without spermatozoa inside the lumen. For the diploid ones, three out of them were sterile, presenting some endogenous spermatogonia inside the germinal compartment (S3, Table 3), and the other two individuals had no germ cells inside the testes (S3, Table 3 ).

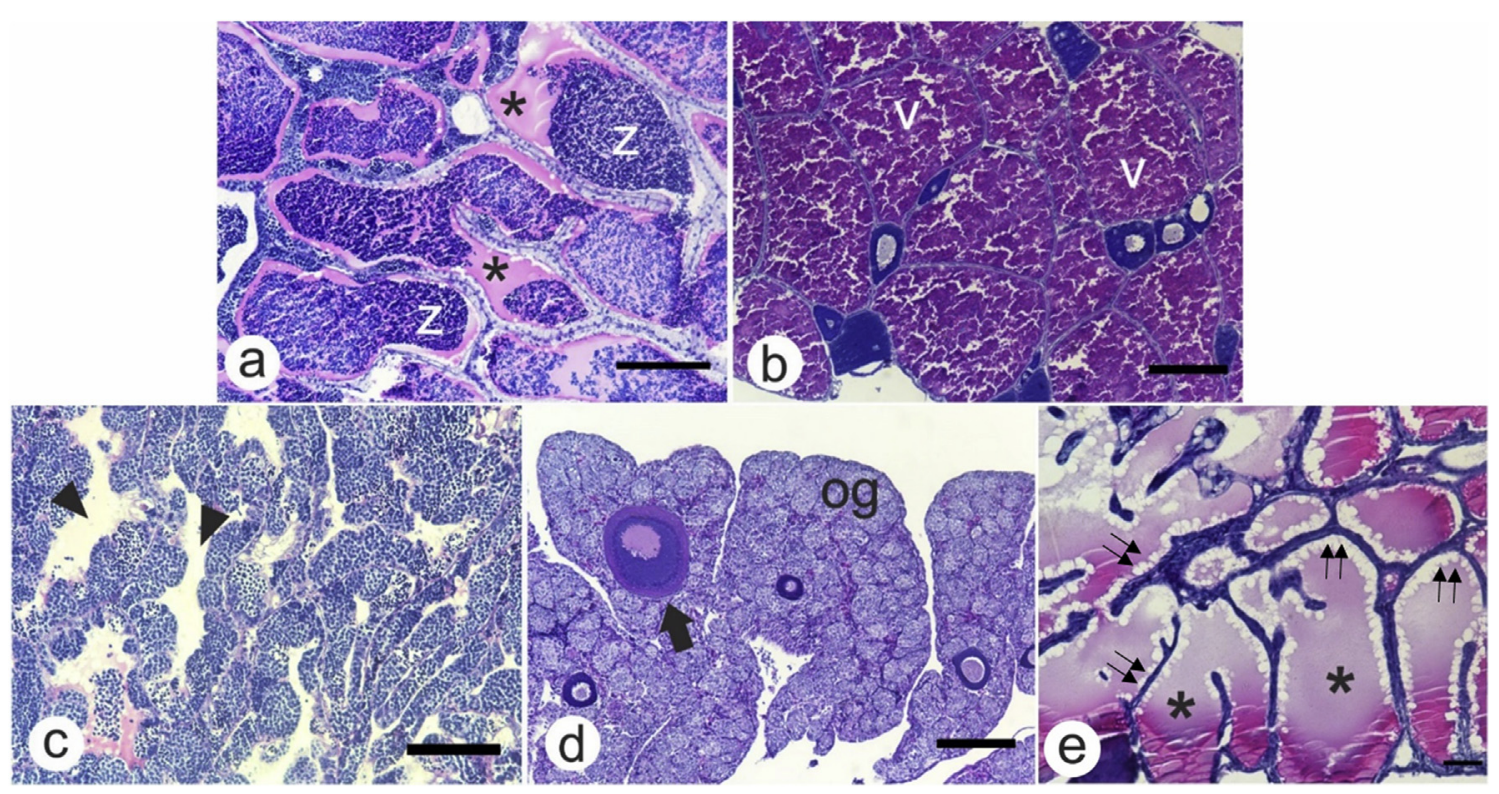

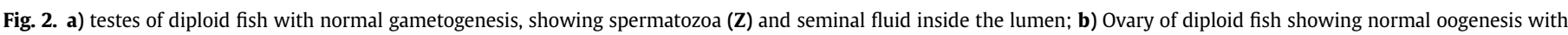

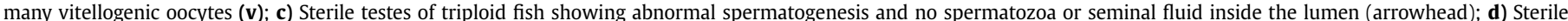

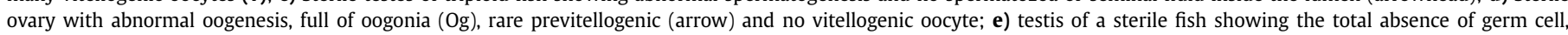
presenting a prominent lumen (asterisks), and free space for transplanted germ cell colonization (double arrow). 
Table 3

Specimens resulting from artificial fertilization between Astyanax altiparanae female and male of the other studied species. $(\mathrm{n}=\mathrm{number}$ of individuals).

\begin{tabular}{lrrrrrrrrrr}
\hline Diploid specimens & \multicolumn{2}{c}{$\begin{array}{c}\text { Astyanax } \\
\text { altiparanae }\end{array}$} & \multicolumn{2}{c}{$\begin{array}{c}\text { Astyanax } \\
\text { fasciatus }\end{array}$} & \multicolumn{2}{c}{$\begin{array}{c}\text { Astyanax } \\
\text { schubarti }\end{array}$} & \multicolumn{2}{c}{$\begin{array}{c}\text { Oligosarcus } \\
\text { pintoi }\end{array}$} & $\begin{array}{c}\text { Hyphessobrycon } \\
\text { anisitsi }\end{array}$ \\
\hline Gametogenesis & Male & Female & Male & Female & Male & Female & Male & Female & Male & Female \\
\hline Normal & 7 & 12 & 1 & 0 & 0 & 3 & 1 & 1 & 0 & 0 \\
No gametes & 0 & 0 & 1 & 0 & 5 & 0 & 5 & 0 & 8 & 0 \\
Sterile with germ cells & 0 & 0 & 4 & 0 & 6 & 1 & 0 & 3 & 0 & 13 \\
Sterile without germ cells & 0 & 0 & 1 & 0 & 0 & 0 & 0 & 0 & 0 & 0 \\
\hline
\end{tabular}

\begin{tabular}{|c|c|c|c|c|c|c|c|c|c|c|}
\hline \multicolumn{11}{|l|}{ Triploid specimens } \\
\hline Gametogenesis & Male & Female & Male & Female & Male & Female & Male & Female & Male & Female \\
\hline Normal & 0 & 2 & 0 & 0 & 0 & 1 & 2 & 0 & 4 & 1 \\
\hline No gametes & 8 & 0 & 0 & 0 & 6 & 0 & 10 & 0 & 2 & 0 \\
\hline Sterile with germ cells & 0 & 14 & 2 & 4 & 3 & 1 & 0 & 1 & 0 & 0 \\
\hline Sterile without germ cells & 0 & 0 & 10 & 0 & 2 & 0 & 0 & 0 & 0 & 0 \\
\hline
\end{tabular}

Normal $=$ Specimens showing normal gametogenesis

No gametes $=$ Specimens showing normal gametogenesis without production of gametes

Sterile with germ cells $=$ Specimens showing mainly oogonia, in case of female, and spermatogonia, in case of male, into their gonads

Sterile without germ cells $=$ Specimens showing only somatic cells into their gonads .

\subsection{A. altiparanae $x$ Oligosarcus pintoi crossing}

Among diploid male hybrid between A. altiparanae and Oligosarcus pintoi, one out of six individuals showed normal spermatogenesis (S4, Table 3), and the other five specimens presented normal gametogenesis without any spermatozoa in the lumen (S4, Table 3). Seminal fluid was also observed. Among diploid females, one presented normal oogenesis (S4, Table 3), and the other three were sterile, showing very thin ovary, filled with oogonia and scarce previtellogenic oocytes (S4, Table 3). Among triploid males, two out of 12 had normal spermatogenesis, and ten fish showed no spermatozoa inside the lumen (similar to the diploid one). Among females, one out of four had normal oogenesis, and the other three had ovaries that were sterile but had germ cells (S4, Table 3).

\subsection{A. altiparanae $x$ Hyphessobrycon anisitsi crossing}

Male diploid hybrids between A. altiparanae and Hyphessobrycon anisitsi presented all testes with normal spermatogenesis but no spermatozoa inside the lumen (S5, Table 3), and all the females were sterile, presenting some previtellogenic oocytes and many oogonia (S5, Table 3). Among triploid males, four out of six had normal spermatogenesis (S5, Table 3), and the other two presented apparently normal spermatogenesis without spermatozoa inside the lumen. The single female presented normal oogenesis (S5, Table 3).

\section{Discussion}

In this study, a combination of various hybrids associated with triploidization was evaluated in order to achieve ideal sterile fish to be used as host in surrogate technology programs.

Surprisingly, some triploid females of $A$. altiparanae presented vitellogenic oocytes at 9-months-age, indicating that triploidization does not ensure permanent sterilization in this species. In previous works from this lab, a histological analysis of the same kind of triploids revealed $100 \%$ sterile females at 6 -months of age. It suggests that aging may recover fertility within A. altiparanae triploids, as similarly observed in other teleost $[13,14]$. Astyanax altiparanae triploid males presented apparently normal gametogenesis, showing the entire lineage of germ cells (spermatogonia, spermatocytes, spermatid). There were no fully-grown spermatozoa inside the epithelium, showing that the differentiation of spermatid into spermatozoa during spermiogenesis is affected by triploidization process. Thus, triploids may not be effective for surrogate technologies because females recover fertility, and there is no space on male gonads epithelium.

On the other hand, all of the 13 female hybrids that resulted from $A$. altiparanae and $H$. anisitsi crossing were sterile, and the triploid hybrids offspring arising from $A$. altiparanae and $A$. fasciatus were $100 \%$ sterile $(\mathrm{n}=16)$ for both males and females, in addition to presenting not fertility recovery with aging. However, some of them presented endogenous germ cells that occupied the stem cell niche, and this fact theoretically may reduce the colonization success of the transplanted cells. In order to develop exogenous (transplanted) germ cells in a host gonad, several factors related to physiological and histological compatibility are necessary.

The testes of most of the triploid hybrid offspring between A. altiparanae $\mathrm{x}$ A. fasciatus ( 10 out of 12 ) did not present germ cells, although all the remaining supporting cells including Leydig, Sertoli, myomeres, vases, and other somatic cells were present. Since, supposedly transplanted germ cells may find adequate space and supporting cells in order to proceed gametogenesis, these offspring specimens were considered as ideal hosts.

In conclusion, four types of diploid hybrids and triploid hybrids were evaluated, and the production of a permanent sterile fish was achieved within triploid hybrids. Such a technique depends however on the combination of the parental crosses and only one cross produced such an ideal sterile fish. As established for the first time, an effective procedure applicable for mass production of host species presenting permanent stem-cell niches that may be colonized by the transplanted cells was achieved. Such a methodology opens new insights for application of surrogate technologies.

\section{Acknowledgements}

Supported by FAPESP 2010/17429-1 and 2011/11664-1

\section{Appendix A. Supplementary data}

Supplementary data related to this article can be found at https://doi.org/10.1016/j.theriogenology.2017.12.013.

\section{References}

[1] Lacerda SMSN, Costa GMJ, Campos-Junior PH a, Segatelli TM, Yazawa R, Takeuchi Y, et al. Germ cell transplantation as a potential biotechnological approach to fish reproduction. Fish Physiol Biochem 2013;39:3-11.

[2] Yasui GS, Fujimoto T, Sakao S, Yamaha E, Arai K. Production of loach 
(Misgurnus anguillicaudatus) germ-line chimera using transplantation of primordial germ cells isolated from cryopreserved blastomeres. J Animal Sci 2011;89:2380-8.

[3] Duhan RA. Aquaculture and fisheries biotechnology: genetic approaches. CABI; 2004.

[4] Yamaha E, Murakami M, Hada K, Otani S, Fujimoto T, Tanaka M, et al. Recovery of fertility in male hybrids of a cross between goldfish and common carp by transplantation of PGC (primordial germ cell)-containing graft. Genetica 2003;119:121-31.

[5] Okutsu T, Shikina S, Kanno M, Takeuchi Y, Yoshizaki G. Production of trout offspring from triploid salmon parents. Science 2007;317:1517.

[6] Hamasaki M, Takeuchi Y, Miyaki K, Yoshizaki G. Gonadal development and fertility of triploid grass puffer Takifugu niphobles induced by cold shock treatment. Mar Biotechnol 2013;15:133-44.

[7] do Nascimento NF, Pereira-Santos M, Piva LH, Manzini B, Fujimoto T, Senhorini JA, et al. Growth, fatty acid composition, and reproductive parameters of diploid and triploid yellowtail tetra Astyanax altiparanae. Aquaculture 2017;471:163-71.
[8] Brasileira F. Livro Vermelho Livro Vermelho Fauna Bras. vol. I. [n.d].

[9] Yasui GS, Senhorini J a, Shimoda E, Pereira-Santos M, Nakaghi LSO, Fujimoto T, et al. Improvement of gamete quality and its short-term storage: an approach for biotechnology in laboratory fish. Animal 2014;9:464-70.

[10] Adamov NSMa. Triploidização na espécie de lambari a styanax altiparanae. Pontifícia Universidade Católica De Campinas; 2013.

[11] Pereira-Santos, Matheus, Shimoda, Eduardo, Andrade, André Furugen Cesar Silva, Luciano Andrade, Fujimoto, Takafumi, Senhorini, José Augusto, Yasui G Shigueki, and Okada LS. Grooves surrounding the micropyle decrease the inseminating dose in fish n.d.

[12] Xavier PLP. Protocolo de fixação de amostras e mensuração da ploidia em peixes por citometria de fluxo. 2013.

[13] Schafhauser-Smith D. The reproductive physiology of three age classes of adult female diploid and triploid brook trout (Salvelinus fontinalis). Fish Physiol Biochem 2001;25:319-33.

[14] Manning AJ, Burton MPM, Crim LW. Reproductive evaluation of triploid yellowtail flounder, Limanda ferruginea (Storer). Aquaculture 2004;242: 625-40. 